\title{
The Effectiveness Of Community Industrial Development Programs: A Study Of A Development District In Southern Appalachia\#
}

\author{
Osbin L. Ervin*
}

\section{INTRODUCTION}

Over the last two decades, the industrial development of southern Appalachian communities has become a matter of public policy. This is clear regardless of the level of government on which one focuses attention. At the national level, the Economic Development and Public Works Act of 1965 authorizes and provides funding for substate economic development districts and provides grants and loans directly to local communities for support of industrial development programs. ${ }^{1}$ At the state level, enabling legislation authorizes counties and municipalities to charter industrial development corporations and to issue tax-exempt municipal bonds to aid manufacturing companies, and administrative agencies provide a wide range of industrial development services to the local governments of the state. ${ }^{2}$ And, a number of industrial development programs and activities, including promotional campaigns and tax concessions, have their origins in the local governments of the region. ${ }^{3}$

Most industrial development programs and activities, regardless of the level of government in which they originate or by which they are authorized, are subject to the policy preferences of the multitude of local communities across the region. It is in the local community that, in most cases, development goals (albeit loosely articulated) are established and instruments for their achievement selected.

In recent years, these local governments have become progressively more involved and active in efforts to attract manufacturing companies. Until the middle 1950's industrial aid bonds and tax concessions were about the only ways in which local governments participated directly in plant locations and industrial development. Beginning in the middle 1950 's, local governments have come to assume a broader role in the industrial development of their communities. This broader role includes the formation of public industrial development corporations, the appoint-

\footnotetext{
\#Parts of this research were supported by the National Science Foundation RANN Program under NSF Interagency Agreement No. AAA-R-4-79 with the Oak Ridge National Laboratory. The author wishes to thank Richard J. Olsen and Alfred H. Voelker of ORNL for their helpful criticisms and suggestions during the course of the research.

*Assistant Professor of Political Science, Southern Illinois University at Carbondale.
} 
ment of full-time industrial development agents, the construction and supervision of community industrial parks, and the development of a community infrastructure of public services and facilities. ${ }^{4}$

The immediate or first-order objective of local government industrial development efforts is straightforward and obvious. It is to attract manufacturing companies and the related jobs to the community.

Citizens and private organizations in the communities of the region are, in general, highly supportive of the various government programs to attract industry. Citizens demonstrate their support in overwhelming approvals of local industrial bond referenda, ${ }^{5}$ and chambers of commerce and other business and civic organizations often assist in local government efforts or develop complimentary programs.

A cursory look at the economy of southern Appalachia suggests the reasons for vigorous government programs and strong citizen and group support for industrial development. In simplest terms, (and as is well known), per capita income in the region has for decades lagged well behind that for the rest of the nation. This is reflected in the lives of the people in terms of inadequate housing, medical care, public schools, and nutrition. Federal government policy is directed toward improving the economy of the region vis-a-vis the nation; states seek to increase the tax base and decrease public-aid expenditures; and governments, citizens and business groups at the local level associate industrial development with some element of community prosperity (increased tax base, higher individual incomes, increased spending, better schools and public services, etc.).

There is room for honest disagreement about the best approach by the various governments to the economic development of southern Appalachian communities. (In many communities, industrial development may not be the best route to new jobs.) However, it is difficult to find fault with the aspirations of local officials and citizens to collectively improve community economic conditions. There is hardly another matter more thoroughly affecting their lives.

Industrial development in southern Appalachian communities is indeed a multi-faceted, strongly supported, and well intentioned public policy. However, interesting and important questions regarding the actual effectiveness of development programs and activities remain. The location of manufacturing plants is a complex process in which a number of very important economic and geographic factors are typically involved. ${ }^{6}$ In the face of these major economic and geographic forces (e.g., labor costs and market considerations) that shape the location of plants, one wonders how much difference local policies and efforts really make. Or, to state the problem somewhat differently, one wonders how effective community industrial development programs are in achieving the objective of attracting manufacturing companies and related jobs. Further, if a positive relationship between effort and new plants exists in the aggregate, additional questions concerning the relationship between specific local programs and the location preferences of various kinds of manufac- 
turing companies need to be dealt with. It is to these and related questions that this paper is directed. The data with which these questions are addressed come from a 16-county economic development district in east Tennessee- the East Tennessee Development District (ETDD).

Before turning to the data and the specific hypotheses to be tested, it is important to briefly look at the various local government programs and activities to which the data and hypotheses are pertinent.

\section{VARIABLES IN LOCAL GOVERNMENT EFFORTS TO ATTRACT INDUSTRY}

Cities and counties in southern Appalachia attempt to attract manufacturing companies to their communities in a wide range of ways. ${ }^{7}$ However, seven variables are particularly salient in Tennessee communities, and they appear to be a reliable indicator of aggregate local government effort to attract industry. The seven variables are: (1) tax concessions, (2) industrial aid bonds, (3) industrial park development, (4) federal EDA grants, (5) public industrial development corporations, (6) industrial development agents, and (7) property taxes.

\section{Tax Concessions ${ }^{8}$}

Exemption from local property taxes is an old and very controversial location inducement to industry. It appears to have been more widely used in the 1920's and 30's than in the period since World War II. ${ }^{9}$ In most uses of this instrument, the company is exempted from all or a portion of local property taxes for a period of up to ten years. The exemption may be for all local property taxes except the portion earmarked for public schools. ${ }^{10}$

Preferential tax treatment for industry is not now and has never been authorized in most states. In a 1965 survey, concessions were authorized in only 17 states. $^{11}$ Tennessee is not among the states authorizing exemptions, and it appears that the state constitution denies municipalities the power to grant exemptions. ${ }^{12}$

Nonetheless, Tennessee cities and counties have in the past granted tax concessions to manufacturing companies. In a 1947 survey, about 25 percent of the responding municipalities indicated that they had given exemptions of one kind or another, ${ }^{13}$ and interviews with officials in the ETDD indicate that during the 1950's and 60's a number of counties and municipalities in the study area indeed granted exemptions. These exemptions apparently are granted in negotiations between local officials and plant representatives. Typically, the company is exempt from all property taxes and in lieu payments for a period of four or five years, then it pays an escalating percentage of the annual assessment for several years. Finally, the company pays the prevailing tax rate on the assessed value of its plant. Some of these exemptions may be a result of local government ownership of the property (land and buildings). In these cases, negotiations focus on the question of in lieu payments. ${ }^{14}$ 
It is very difficult to estimate the degree to which tax concessions are granted today. However, discussions with officials in the development district suggest that they are not as prevalent now as they were in earlier years.

\section{Bond Financing ${ }^{15}$}

A second instrument in local government efforts to attract industry is municipal industrial aid bonds (IAB's). Local governments and public industrial development corporations issue the bonds to buy and develop land and construct buildings for lease or sale to manufacturing companies. Typically, the municipality, county, or public corporation will sell bonds for the purchase of land and the construction of a plant for a particular company. The plant is then leased to the company for a period of years and at a rental sufficient to pay interest and principal on the bonds. ${ }^{16}$

As is well known, the interest on IAB's is exempt from the federal income tax, and, in Tennessee, they are also exempt from state, county, and municipal taxes. ${ }^{17}$ As a result, local governments are able to borrow funds at interest rates lower than those available to private borrowers. In Tennessee, interest rates on industrial aid bonds varied between 3 percent and $77 / 8$ percent during the $1960-1972$ period. The low interest rates are generally passed on from the local government borrower to the lessee of the land and buildings. Thus, this form of financing means a savings to the relocating or expanding company. In addition to the savings made possible by the low interest loan, the lessee does not have to pay local property taxes. The local governments involved may, however, require payments in lieu of taxes.

Authorization for Tennessee municipalities, counties, and public corporations to issue industrial aid bonds is contained in four acts of the Tennessee Legislature: The Industrial Building Revenue Bond Act of 1951, The Industrial Building Bond Act of 1955, The Industrial Development Corporations Act of 1955, and The Industrial Park Act of 1959.1

This package of state legislation extends to local governments a potentially powerful financial instrument for use in their efforts to attract industry, and state data for the ETDD indicate that Tennessee communities have made extensive use of the instrument. Five ETDD communities have issued IAB's amounting to over $\$ 7,000,000.00$ each, and several others have made issues totaling over $\$ 1,000,000.00 .{ }^{19}$

\section{Industrial Park Development ${ }^{20}$}

Both industrial aid bonds and EDA grants are used in the development of industrial parks. Therefore, as an instrument of local policy, industrial park development overlaps somewhat with these other two programs. However, the planned development of large tracts of land into industrial areas is a community undertaking that goes beyond individual bond issues or grant applications. The efforts and resources of a large number 
of private individuals and government officials are typically necessary for the success of the project.

The Tennessee Industrial Park Act defines an industrial park as:

Land and rights, easements and franchises relating thereto and may include adequate roads and streets, water and sewer facilities, utilities, and docks and terminals, as required for the use of industry, and such appurtenant land for necessary incidental use. Industrial park may also include a site for the establishments or location of a single industry. ${ }^{21}$

In general, industrial parks in the ETDD are level tracts of land developed with utilities and access roads, designed to accommodate several plants, and controlled by a local government or public corporation.

To the degree that the development of industrial parks provides developed, serviced, accessible land for industrial use, they are probably an important instrument in community industrial development policy. In a recent study of industrial parks in East Tennessee, Daniel Good concluded that the parks had been generally effective in attracting industry. ${ }^{22}$ Good noted that there have been few other studies of the actual effectiveness of industrial parks in attracting manufacturing companies.

The development of an industrial park can be a systematic and efficient way for the small community to make land and the necessary services and facilities available to companies. In the absence of an industrial park, companies may locate on sites widely scattered about the community. The extension of utilities and other public services to these scattered sites can place a heavy financial burden on local units of government. The industrial park idea and the availability of financial aids for park development offers communities the option of a packaged, economical provision of land and services to meet community development objectives.

\section{Economic Development Administration (EDA) Grants ${ }^{23}$}

The industrial aid bond laws of 1951 and 1955 and The Industrial Park Act of 1959 provide Tennessee municipalities and counties with powerful instruments for the purchase of industrial land and construction of plants. However, these statutes do not provide local governments with financial aid for providing necessary public utilities, streets, access roads, and other services and facilities necessary to industrial sites. The Industrial Park Act empowers local governments to provide services in support of industrial parks, but it does not provide funding or financial assistance.

The Public Works and Economic Development Act of 1965 seems to fill this gap in industrial development financing. The act authorizes federal grants to local governments to "help provide public works needed to attract new industry and encourage business expansion."24 A wide variety of local projects that would improve public services and facilities are eligible, including road construction, sewer systems, and water works. 
In addition, supplementary grants are available for severely distressed areas which may bring the total to as much as 80 percent of the project costs.

\section{Public Industrial Development Corporations ${ }^{25}$}

The local community is often exhorted by state and national agencies to "organize" as a major first step in industrial development, and indeed, development organizations abound in communities across the country. A 1958 study revealed that there were 14,000 community industrial development organizations in the country at that time..$^{26}$ Of the 14,000 , four thousand were directly supported by government funds. ${ }^{27}$

These local organizations vary considerably in structure and motives. Some are loosely organized groups of comrnunity notables who are oriented toward community welfare, others are profit-seeking private corporations, and still others are state chartered, non-profit, public corporations. Such organizations maý aid local industrial development efforts in one or more of a set of ways enumerated by Norman:

1. In making capital available without the necessity of the company using its own funds or providing for capital itself;

2. in obtaining land or other important assets at a price which the industry itself might not be able to obtain;

3 . in providing an arm length's method of obtaining tax advantages-local, state, and federal;

4. in tying together local and community interests with those of the new industry, thus assuring continued local acceptance of the new industry. ${ }^{28}$

To these items Norman might have added the role of intermediary between the firm and local government units and other community organizations with which the company needs to negotiate buildings, utilities, industrial park space, or other plant needs.

There are four types of local industrial development organizations in the ETDD: ${ }^{29}$ (1) public corporations (most of these established under the Industrial Development Corporations Act of 1955), (2) private, profit-oriented corporations, (3) private, nonprofit corporations, and (4) local voluntary organizations, including Chambers of Commerce. Only public corporations formed under the 1955 act are authorized to issue industrial development bonds. These local government sponsored corporations can:

Acquire, own, lease, and dispose of properties to the end that such corporations may be able to promote industry and develop trade by inducing manufacturing, industrial, governmental and commercial enterprises to locate in or remain in this state and further the use of its agricultural products and natural resources, and to vest such corporations with all powers that may be necessary to enable them to accomplish such purposes. ${ }^{30}$ 
This makes these public corporations the most efficacious of the local industrial development organizations, and, since this paper focuses on local government activities, only such public corporations are considered in assessments of community industrial development effort.

Most of the communities in the ETDD participate in a county-wide development corporation, and several of the region's cities have formed their own corporations. Each corporation is managed by a board of directors of from three to nine members. The various municipalities in a county are typically represented on the board of a county's corporation.

\section{The Industrial Development Agent ${ }^{31}$}

One of the most interesting policy options available to local governments is the creation and funding of the position of local industrial development commissioner or representative. These agents of local government consider themselves industrial development professionals, and they often combine the skills of an industrial economist with those of a salesman. The task of the local agent is to attract manufacturing companies to the community. (If he cannot do this, then he is likely to be dismissed or to voluntarily move on to another community.)

Local industrial development agents are normally employed by a city or county, or by a public development corporation acting as an extension of a unit of local government. The office of the agent is likely to be found in the courthouse or city hall, in proximity to the offices of other local officials.

Local industrial development agents in the ETDD appear to understand that plant location is a complex process in which many factors play a role. In general, the first major step in their approach to industrial development is to assess and seek to improve community conditions with regard to one or more major plant location factors (i.e., industrial land, utilities). The second step focuses on promoting and "selling" the community. The agent must make the community appear attractive enough to warrant visits by plant representatives, and once the representatives are in the community, he must convince them that the community, its people, and plant facilities would meet the needs of their company. A major role of the local agent in this process is as negotiator between plant representatives and the various governments and relevant organizations in the local area. If, for example, a natural gas line must be extended to the plant site, the local agent is expected to ensure that arrangements are satisfactory to both the plant representatives and the utilities board.

\section{Property Taxes ${ }^{32}$}

From the perspective of local government affairs, the property tax is one of the most interesting variables in community industrial development policy. Local tax rates, in contrast to such plant location factors as markets and labor costs, can be immediately and significantly altered 
by local government action, and it is not uncommon to hear local governments exhorted to keep taxes low or else the area will not be able to compete for new industry.

Data showing that local taxes are actually important in plant location decisions are considerably more difficult to find than are the exhortations and $a$ priori arguments. The empirical findings available generally indicate that property taxes are of no more than secondary importance in plant location decisions. ${ }^{33}$ However, this factor probably increases in importance as the plant location decision becomes more site specific ${ }^{34}$ (i.e., as the decision moves from selection of region to selection of community and plant site); at the point in the location decision making process at which local governments are most efficacious, the property tax is at its maximum importance.

\section{HYPOTHESES}

The obvious and major hypothesis suggested by the array of community industrial development programs and activities above is: The more vigorous the local government effort to attract manufacturing plants, the more likely are plants to locate in the community.

With respect to specific programs, the hypothesized relationships are:

1. The more disposed the community is to grant tax concessions, the more likely are manufacturing companies to locate in the community.

2. Communities that issue industrial aid bonds to attract and aid new manufacturing plants will have a greater influx of new plants than will other communities.

3. The more active the community is with respect to industrial park development, the more likely it is to attract new manufacturing plants.

4. Manufacturing plants will tend to locate in communities that are characterized by the use of federal EDA grants for industrial development.

5. Manufacturing companies will tend to locate in communities that are served by a public industrial development corporation or board.

6. Communities that employ a full-time industrial development agent will be more successful than other communities in attracting new plants and jobs.

7. The lower the tax on property, the more likely are manufacturing companies to locate in the community.

At this point, a distinction needs to be made among the various programs and activities in the hypotheses above. The programs in the first six hypotheses are usually designed explicitly for industrial development - to attract or aid prospective manufacturing companies. Variations in community participation in the programs can reasonably be assumed to 
reflect differences in community attitudes toward industrial development and in community effort to recruit industry. These programs, activities, and practices are conceptualized as "effort" variables.

The program in the seventh hypothesis-low property taxes, is a different kind of variable. It cannot be assumed that variations in tax rates reflect differences in community attitudes toward industrial development. Low tax rates may be primarily a result of economic conditions, leadership attitudes, and citizen preferences rather than of a perception of tax influences on industrial development. For this reason, tax rates are not conceptualized as a part of the industrial development effort of a community. They are thought of as local government or community attributes that may be important in the location of plants. They may, of course, be consciously used as instruments in industrial development by some local governments.

\section{DATA AND ANALYTIC APPROACH}

In order to test the hypotheses, data on plant locations and local government programs and activities for the 1960-1972 period were collected for the 45 municipalities of the 16-county ETDD.

The comparison of communities within a rather small 16-county area puts this study very explicitly into an intraregional framework. It was felt that comparison of communities within the same general region was the appropriate approach for studying relationships between community industrial development and local government programs. This conviction has its origins in the industrial location literature.

The literature on industrial location suggests strongly that plant location decision-making is a multilevel or multistage process, in which company decision-makers first select a region (and perhaps a subregion) and then a particular community and plant site. ${ }^{35}$ A second body of the industrial location literature deals with the importance of the various location factors at the different stages of the decision-making process, and here it suggests equally strongly that local government programs and activities are of most importance at the point at which the community and plant site are selected. ${ }^{36}$ Thus, it seems that differentials in plant locations and local government efforts among communities of the same region or subrégion is the appropriate place to look in studying the effectiveness of local programs and activities.

Plant location and employment data for the 45 communities were abstracted from state and local industrial directories ${ }^{37}$ and verified in personal interviews with knowledgeable persons in each of the counties of the development district. The result was a reliable list of manufacturing companies, with associated employment and product data, locating in or in the vicinity of each of the communities over the 12-year period. ${ }^{38}$ This is highly important, for valid statements about relationships between local policy and plant locations depend on accurate industrial location data. 
Data on local government effort (bond issues, tax concessions, industrial parks, etc.) were taken from records of the state Department of Economic and Community Development, the local development district, and the Tennessee Taxpayers Association. As in the case of plant location data, verification and supplementary data. were obtained in personal interviews with local and regional officials.

The data suggest a great deal of activity with respect to both industrial development efforts and plant locations. During the 12-year period, 524 manufacturing plants opened their doors and initially made 22,802 jobs available. The intercommunity range in new manufacturing jobs associated with the plants is 0 to 8,280 . The magnitude and inter-community range of community industrial development efforts is also impressive. Over the 12-year period, the local governments of the region formed 28 industrial development boards, floated 51 industrial aid bond issues totaling over 50 million dollars, developed 25 industrial parks, and acquired almost 8 million dollars in EDA industrial development grants. The range in aggregate effort is from zero to that of the community that has floated 8 bond issues totaling over $\$ 7,000,000$ has acquired $\$ 160,000$ in EDA funds, and that developed a large industrial park early in the study period.

After plant location and local effort data for each municipality were coded, composite measures of new manufacturing jobs and industrial development effort were correlated to determine if an association exists in the aggregate. ${ }^{39}$ Following this correlation of composite measures, the variables making up each index were disaggregated and correlated to determine relationships between specific local programs and various kinds of new plants and jobs. An attempt was made to minimize the effects of intervening variables.

In the analysis of relationships between specific local programs and the location of plants in specific groups of manufacturing industries, the effects of several community variables were held constant by means of partial correlation procedures. A second major control mechanism of the study was the intraregional framework discussed earlier; many of the plant location factors of most overall importance to relocating manufacturing companies diminish in importance as the decision-making process moves from the selection of a major region to the selection of a specific community within a region. In an analysis of the communities of 16 contiguous and relatively homogeneous counties, inter-community variations on labor, market, and transportation factors are likely to be considerably less than would be the case in interregional comparisons.

\section{FINDINGS}

In Table 1, the rank order of the communities on the indices of new manufacturing jobs (as percentage of 1970 population) and of community effort are set adjacent to one another..$^{40}$ The Spearman correlation coefficient between the two rank orders is 0.4110 . When the communi- 
ties are ranked with respect to new jobs without controlling for community size, then the correlation between indices increases to 0.7461 .

The 0.4110 correlation coefficient signifies a moderately strong, positive association between the two rank orders; during the 1960-1972 period, there was a tendency for new manufacturing plants and related jobs to locate in communities that were making a greater effort to attract manu-

TABLE 1

Rank-Order Correlation Between Indices of Local Government Effort and New Manufacturing Jobs (1960-1972)1

\begin{tabular}{llcl}
\hline & Local Effort 2 & \multicolumn{2}{l}{ New Jobs (as o of 1970 pop.) } \\
\cline { 2 - 4 } Rank & Municipality & Rank & Municipality \\
\hline 1 & Northfield & 1 & Torrington \\
2 & Mitchell & 2 & Warner \\
3 & Edmonton & 3 & Grand Junction \\
4 & Dickinson & 4 & Winfield \\
5 & Warner & 5 & Emmitsburg \\
6 & Chadron & 6 & Edmonton \\
7 & Fulton & 7 & Alpena \\
8 & Caldwell & 8 & Northfield \\
9 & Haviland & 9 & Haviland \\
10 & Ankeny & 10 & Dickinson \\
11 & Scottsbluff & 11 & Bremerton \\
12 & Kernville & 12 & Freeman \\
13 & Roseburg & 13 & Hays \\
14 & Sidney & 14 & Logan \\
15 & Marshalltown & 15 & Benidict \\
16 & Freeman & 16 & Marshalltown \\
17 & Torrington & 17 & Rangely \\
18 & Logan & 18 & North Newton \\
19 & Emmitsburg & 19 & Caldwell \\
20 & Platteville & 20 & Willmar \\
21 & Bozeman & 21 & Sherman \\
22 & Winfield & 22 & Mitchell \\
23 & Saint Benidict & 23 & Roseburg \\
24 & Hobbs & 24 & Casper \\
25 & Willmar & 25 & Scottsbluff \\
26 & Sherman & 26 & Fulton \\
27 & North Newton & 27 & Mt. Pleasani \\
28 & Hays & 28 & Sidney \\
29 & Mt. Pleasant & 29 & Ankeny \\
30 & Kirkland & 30 & Lancaster \\
31 & Lancaster & 31 & Victorville \\
32 & Miles City & 32 & Chadron \\
33 & Victorville & 33 & Bozeman \\
34 & Grand Junction & 34 & Kerrville \\
35 & Bremerton & 35 & Platteville \\
36 & Rangely & 37 & Brownwood \\
37 & Kearney & Hobbs \\
38 & Litchfield & 38 & Kirkland \\
39 & Thatcher & Litchfield \\
40 & Alpena & Miles City \\
& & &
\end{tabular}


TABLE 1 (Cont'ed)

\begin{tabular}{|c|c|c|c|}
\hline \multicolumn{2}{|c|}{ Local Effort 2} & Rark & Municipality \\
\hline Rank & Municipality & \multicolumn{2}{|c|}{ New Jobs (as \% of 1970 pop.) } \\
\hline$\overline{41}$ & Casper & 41 & Kearney \\
\hline 42 & Ashland & 42 & Thatcher \\
\hline 43 & Brownwood & 43 & Ashland \\
\hline 44 & Sparkhill & 44 & Sparkhill \\
\hline 45 & Macomb & 45 & Macomb \\
\hline
\end{tabular}

1Spearman's rank-order correlation coefficient $=0.4110$

2The six effort variables (Development Corporations, development agents, Industrial bond financing, Industrial parks, EDA grants, and tax concessions) were combined to form the rank order of municipalities on a composite index of "local government effort" to attract industry. The combination was performed by separating the values for each of the six local effort variables into four categories. Each community then was given a value of $0,1,2$, or 3 on each of the variables. These values were then summed for the incex score. The scale is an additive index of the sort discussed in Johan Galtung, Theory and Methods of Social Research (Columbia University Press, 1967), pp. 250-265. Also see notes 3 through 8 of Table 2.

facturing companies. There are a number of individual cases in the data that strongly support the association. For example, Northfield and Warner have waged very vigorous, well-coordinated industrial recruitment efforts, and both are among the region's leaders in new plants and jobs. On the other hand, Sparkhill and Macomb have shown no interest in attracting manufacturing plants, and none have located in the two communities during the study period.

When the seven specific local programs are studied, partial correlation coefficients (Table 2) indicate that tax rates, bond financing, industrial parks, and EDA grants are associated with the location of new plants and jobs and that these associations vary somewhat among high, medium and low wage industries. ${ }^{41}$ On the other hand, the partials indicate that industrial development corporations, industrial development agents, and tax concessions are not significantly correlated with plant locations and related jobs in the study area.

The effective property tax rates of the counties in which the communities are located are rather strongly correlated with all three measures of total new manufacturing activity (new jobs, new plants, and new plants of 10 or more employees); manufacturing companies tend to locate in or near those communities for which effective county tax rates are lowest. However, this does not appear to hold for high-wage industries. The correlation between location of high-wage industries and effective county tax rates is very weak.

Both of the industrial bond variables (number of issues and dollar volume) are positively correlated with all three aggregate measures of new plants and new jobs. The correlations vary from 0.3908 to 0.7149 . These partials strongly support the hypothesis that communities which are more active with respect to industrial aid bonds will experience a greater influx of new manufacturing plants and jobs than will other communities. Bond financing is associated with locations in both low- 
TABLE 2

FIFTH-ORDER PARTIAL CORRELATION COEFFICIENTS ${ }^{1}$ BETWEEN LOCAL PROGRAMS AND NEW PLANTS AND JOBS IN THE 45 MUNICIPALITIES OF THE DEVELOPMENT DISTRICT (1960-72)

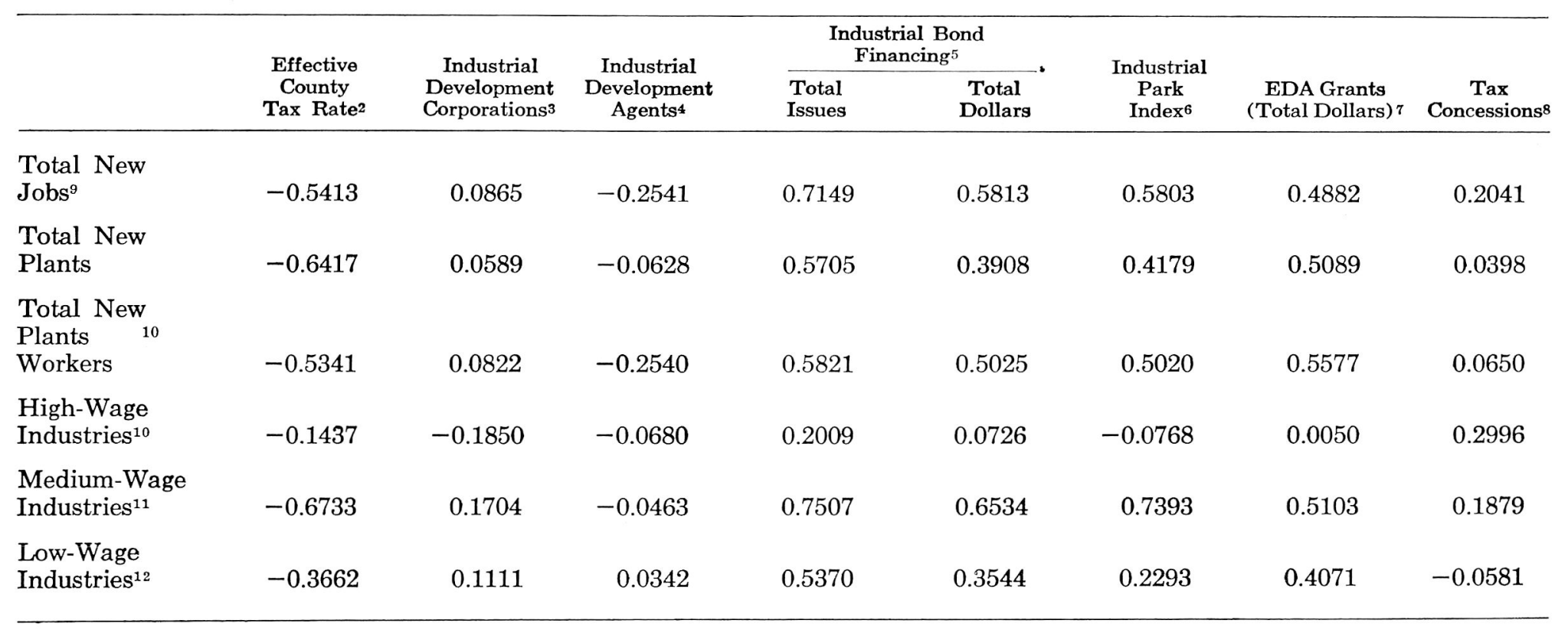




\section{FOOTNOTES FOR TABLE 2}

1The following variables were partialed out: Distance from a metropolitan center, 1960 population, 1960 civilian labor force, 1960 unemployment rate, and 1960 median education.

2Because of the tendency of companies in the area to locate outside the corporate boundaries of communities, only county tax rates were considered. The effective tax rate is defined as: Tax rate $x$ assessed value/actual value. Variable values are mean annual rates for the 12 -year period.

3The number of years over the 12-year period during which a board existed in the municipality and/or parent county.

${ }_{4}$ The number of years over the 12-year period during which the municipality or parent county employed an agent on a full-time basis.

5 Includes bonds issued by counties acting on behalf of specific communities.

6 Each industrial park in the study area was given an attractiveness score based on utilities and services, land availability, cost, transportation, and topography, and attractiveness was then combined with years of availability and acreage to produce an index score (years $X$ acres $X$ attractiveness $[1.1-3.4])$.

7 Includes grants received by counties and utility districts and applied to specific communities.

8 The propensity of the municipality or its parent county to offer tax concessions.

${ }_{9}^{9}$ All new plants and jobs in the development district were assigned to specific communities on the basis of mailing addresses and field surveys. In most cases, plants were located within or very near the corporate boundaries of the municipality to which they were assigned.

10From the perspective of community industrial development efforts and objectives, wage levels were thought to be an important dimension of new manufacturing activity. In order to classify industries, national data on total payroll and total employees were obtained for each industry for the years 1963, 1967, and 1970. Annual industry wages per worker were then computed for each of the three years, and the mean of the three-year sample was used to rank and classify the industries. The cut-off points separating wage group were established at natural breaks in the distribution of annual earnings per worker. Using this approach, high wage industries over the 1960-1972 period are: Petroleum, transportation equipment, primary metals, chemicals, machinery, instruments.

11Medium-wage industries are: Electrical machinery, fabricated metals, printing and publishing, paper and pulp, rubber and plastics, stone, clay and glass, miscellaneous.

12Low-wage industries are: Food, furniture, tobacco, lumber and wood, textiles, leather, apparel. 
wage and medium-wage industries. Associations beween the bond variables and high-wage industries are weak and insignificant.

Associations between plant locations and industrial parks are also positive and rather strong and convincing. As shown in Table 2, the correlation of the industrial park index with total new jobs is 0.5803 , with total new plants 0.4179 , with new plants of 10 or more workers 0.5020 . Apparently, these correlations are due primarily to the locational preferences of medium-wage industries; the partial between industrial parks and medium-wage industries is 0.7393 . The correlations between parks and low-and high-wage industries are very weak, 0.2293 and -0.0768 , respectively.

The fourth program significantly associated with new manufacturing plants and jobs is EDA grants. The amount of EDA funding is positively associated with all three aggregate measures of new manufacturing plants and jobs. When analysis shifts to the three wage classes, there are correlations of 0.4071 and- 0.5103 between the EDA variable and lowand medium-wage industries respectively. The correlation between this local effort variable and the high-wage category, as in earlier cases, is very weak.

The other local effort variables studied are only weakly correlated with the various measures and categories of new manufacturing plants and jobs. Industrial development corporations, industrial agents, and tax concessions do not appear to be associated with the location of manufacturing plants and related jobs in the study area for the period studied.

In terms of the seven hypotheses stated earlier, those concerning tax rates, industrial aid bonds, industrial parks, and EDA grants are generally supported by the analysis. Those concerning industrial development corporations, industrial development agents, and tax concessions are not supported.

\section{DISCUSSION}

\section{Relationships Between the Composite}

Indices of Local Effort and New Jobs

The findings indicate that efforts of local governments to attract manufacturing plants are associated positively with new plants and jobs in manufacturing industries; that is, there is a tendency for companies to locate in communities where vigorous efforts have been made to attract and aid industry.

However, communities should be cautious in the allocation of resources to industrial development planning and recruitment. A strong local effort to attract industry is neither a necessary nor sufficient condition for the industrial development of local communities. There are cases in the study area in which communities that have made little effort to attract industry have undergone rapid growth in new manufacturing plants and jobs. Similarly, cases were studied in which communities 
made vigorous efforts to attract manufacturing companies, but with little success. A closer look at the rank of some of the communities on the two composite indices (Table 1) may be instructive with regard to both the potential and limits of local efforts to attract industry.

The communities of Edmonton, Northfield, and Warner-are examples of communities that rank high on both indices. These three communities have been especially favorable toward new industry with regard to two of the variables in the local effort index-industrial bond financing and industrial parks. The three communities developed industrial parks early in the study period, and each has issued an impressive number and dollar volume of industrial bonds.

The development leaders and local government officials interviewed were unanimous in the belief that local effort has been a major factor in the industrial development of these communities. A common belief of these local leaders and officials was that the community that wishes to industrialize must in all cases provide full-developed sites, and that in some cases additional incentives may be necessary. Edmonton, Northfield, and Warner are, according to these local government officials and development leaders, examples of the kind of impact such a local development effort can have on the economy of: a community.

Next, consider the communities of Chadron, Ankeny, and Platteville. In each case, the community is ranked considerably higher on the index of development effort than on the index of new plants and jobs. The difference in the two positions of Chadron is 26; in the two positions of Ankeny it is 19; and in the case of Platteville the difference is 15. These three communities have been very active in attempting to attract industry, but have had little success.

The three communities are similar in that they are dominated by large. heavily unionized, high-wage companies. Chadron's economy is dominated by a federal weapons contractor, and Ankeny and Platteville (twin cities) are dominated by a large primary metals manufacturer. Interviews with local and regional officials suggest that labor-force characteristics make these two communities unattractive to many relocating companies. The industrial development representatives of both AnkenyPlatteville and Chadron indicated that the three towns had lost industrial prospects because of the high wages and labor union activities associated with existing companies. The industrial development coordinator of the development district summed up his views of industrial development in Chadron by saying, "It is a very difficult town to sell," and the industrial commissioner of Ankeny-Platteville indicated that some of the companies he contacts "end up in the region, but in another community."

Regarding cases such as Chadron, Ankeny and Platteville, it should be remembered that local industrial developnent policies and programs are implemented in an environment containing many factors important to relocating manufacturing companies. Local industrial development 
efforts, no matter how vigorous, are unlikely to be successful in the face of highly negative geographical or economic conditions. A community attempting to industrialize or diversify its manufacturing industry in the face of such negative circumstances should direct its efforts toward industries and companies whose needs are most congruent with local conditions. The Chadron area, for example, has a pool of highly skilled workers, a situation which may be attractive to small, high-technology companies.

Three other communities are also illustrative of relationships between aggregate local efforts and plant locations. These are Grand Junction, Torrington, and Alpena. In each of these cases, the rank on the measure of new jobs is considerably higher than the rank on the local effort index; the difference for Grand Junction is 31, for Torrington 16, and for Alpena 33. The three communities have undergone more industrial growth than would be suggested by references to local programs and activities.

Grand Junction, Torrington, and Alpena are similar in that they are small rural mountain communities that had almost no manufacturing industry prior to the 1960's. The new plants and associated jobs of the 1960-72 period are concentrated in the apparel and textile industries (primarily in apparel). These communities attracted apparel and small textile companies without expending very much effort. This tendency is suggested by other cases in the region-particularly by Winton, an unincorporated mountain community with a population of about 600 . Winton would rank very low on the local effort index but, during the 1960's it attracted two apparel companies that employed almost 600 workers by 1972 .

These communities suggest that there is little or no tendency for apparel companies to prefer communities that are most vigorous in industrial recruitment efforts. It may be that apparel companies are so strongly oriented toward communities with a plentiful supply of lowcost, non-unionized, female labor that local government efforts are actually of little consequence; perhaps apparel companies will locate in the community in which they find labor considerations favorable, regardless of local programs and activities.

\section{Relationships Between Plant Locations and Specific Local Programs}

The matrix of partial correlation coefficients (Table 2) makes it clear that the various local government attributes and development efforts are not uniformly related to the location of manufacturing plants and jobs. The results of the partial correlation analysis indicate that some classes of manufacturing industries prefer communities with certain programs and tax characteristics while other industries have different preferences.

Tax rates, industrial bond financing, industrial parks, and federal (EDA) industrial development grants are associated with plant loca- 
tions in medium and low-wage industries. Companies in these wage classes seem to prefer communities that have been most favorable with respect to these practices and programs. None of the associations hold for high wage industries.

The associations between local programs and. low wage industries do not extend to the industry which, over the :1960-72 period, has contributed the most new plants (68) and jobs $(8,350)$ to the study region-the apparel industry. The study of the two rank orders of communities (Table 1) suggested that locations in the apparel industry are not associated with local development efforts a.s measured by the composite index. Further analysis indicated that apparel industry locations are no more than weakly correlated with any of the local effort or attribute variables measured.

The analysis suggests that, in general, the locational preferences of high wage industries are unaffected by property tax rates or industrial development efforts. This is very important, for these are the industries which may contribute most to the long-term economic and social development of the community. These companies are more likely to be concerned about community amenities and services than are low and medium industries. However, the location of: industries in the high wage class may be related to other local attribute variables such as the quality of public schools. This study did not yield data pertinent to these other possible relationships.

Industrial development corporations, full-time industrial development agents, and tax concessions do not appear to be associated with the locational preferences of manufacturing companies in the study area. Communities which rely heavily on these variables in industrial development efforts are likely to be disappointed.

This finding should not be interpreted as a recommendation to communities that they not form industrial development boards or hire industrial development agents. Communities that wish to attract new industry and that view this matter as public business may find it convenient to form a board and appoint an agent to oversee, coordinate, and administer the various local programs and activities. The public industrial development corporation or board appears to be an efficient and systematic way for the local government unit (county or municipality) to handle industrial bond issues and other matters of industrial development policy. In the absence of an appointed industrial development agent, the work of research, recruitment and coordination must be accomplished by community volunteers and other local government officials. Thus, while local boards and agents do not appear to be effective instruments in attracting plants, local governments may wish to institute local boards and agents as a matter of administrative preference. 
To the student of local government affairs, the finding that tax concessions are not associated with plant locations may be encouraging. Very little can be said on behalf of the practice of extending special tax benefits as an inducement to location. It does not seem to be fair and equitable either to the community's citizens or to established manufacturing companies. The findings of this study suggest that the community which offers tax exemptions and moratoriums is not improving its competitive position vis-a-vis other communities. However, it should be noted that the measurement of tax concessions was very crude; the conclusions, therefore, are no more than tentative.

The relationships between plant locations and bond issues, industrial parks, and EDA grants are suggestive of an underlying capital investment dimension in successful local industrial development efforts. The local governments that have invested in industrial development in terms of land, buildings, industrial parks, and improved utilities and municipal services have, in general been successful in attracting new plants and jobs. Programs that less clearly represent a long-term financial investment, such as tax concessions, development corporations, and industrial agents, do not directly contribute to the industrial development of local communities.

The major capital investment of the communities of the study area is industrial land and buildings. Industrial land is generally controlled by local governments or other public organizations in the development district, whereas in some other parts of the United States land is handled primarily by realtors, banks, and other private developers.

Local government involvement in land acquisition and development in the study area appears to result mainly from two matters: First, investment in industrial land may not yield a return for several years. The investor must be willing to develop the land and then wait patiently for the right companies to come along or for other local conditions to become more favorable to industry. Private developers in the development district studied are, in general, unwilling to do this. Secondly, federal and state legislation encourages local governments in the region to become involved in the acquisition and development of industrial land. (For example, state legislation authorizing low interest industrial bonds and the federal legislation making EDA grants available.)

In essence, the economic condition of communities in Appalachia has been defined by states and the federal government as a public matter and, therefore, appropriate public financial instruments for economic development have been made available to the governments of these communities. Private developers of land have difficulty competing with these publicly funded local units of government, even when they have the inclination. The industrial development coordinator of the development district indicated that a "public commitment" in terms of land, facilities, and services is required if a community of the district is to compete for new industry. 


\section{CONCLUSION}

Communities and regional agencies seeking to attract manufacturing companies need to be knowledgeable and realistic about the potential and limits of local industrial development efforts. The interviews and review of literature conducted in association with this study remind one that the location of manufacturing plants is a very complex process involving many factors, and that local government control or potential influence varies from one factor to another. For example, local governments can do little to alter the availability or cost of labor while, on the other hand, they have a great deal of control over tax rates and municipal services.

Within the framework of this realistic and rather cautious approach, a local government industrial development effort can be effective in attracting industry to the community. In the area and over the period studied in this research, a positive association between local effort and new manufacturing plants does exist. For maximum effectiveness, however, the effort must take into account community conditions and the preferences of various manufacturing industries. With data on these two matters, the local development planner is in position to develop a program or strategy specifically tailored to his communities conditions and objectives.

This research suggests that the strategy should have a public investment program at its core. The programs (i.e., bond financing, industrial park development, and EDA grants) that make land and well-serviced facilities available seem to be more effective in attracting manufacturing companies. The local official should keep in mind, however, that investment programs are not uniformly related to the various types of manufacturing industries, nor do they have an equal likelihood of success in all communities. Local governments seeking to attract new manufacturing jobs should develop an investment strategy that takes into account both the unique characteristics of the community and the particular kinds of manufacturing plants that might be recruited. The community with low tax rates also appears to have an advantage in industrial recruitment, although this does not hold for all industries. Tax exemptions and moratoriums, the activities of public corporations, and the promotional work of full-time agents are generally not very effective programs. This research has dealt only indirectly with public services-through the EDA grants. More research is needed on this dimension; general community services and amenities may be important location determinants in some manufacturing industries.

Local decision-makers should fully utilize the resources of regional planning and research organizations in formulating community development programs and strategies. The information that those agencies can provide may help the local community in avoiding irrational efforts that result simply in a waste of scarce community resources or, even worse, in development gains that are only temporary and that are more than 
offset by losses and distress when a company falters or hurriedly leaves the community. Regional agencies and the research in regional science can aid local officials both in formulating programs most likely to achieve the immediate objective of attracting manufacturing companies and in identifying the long term consequences of their decisions. ${ }^{42}$

Another function that the regional agency can perform in the community industrial development process is to attempt to insure that community influences on industrial location are in the interest of the entire region or subregion as well as to the specific community. An assumption of the research reported in this paper is that local government programs are of maximum importance at the intraregional stage of the plant location decision-making process. Therefore, from a regional perspective, a major effect of local industrial recruitment efforts is to rearrange the spatial distribution of companies that would have located in the region regardless of local programs. It is in the interest of both the region and the community that the spatial arrangement of the various industries be in harmony with the region's economy and natural environment.

There is another important matter in community industrial develop. ment that should not go unmentioned. This paper has addressed only the immediate or short-term objective of community industrial development efforts-the objective of attracting manufacturing companies. Second and third-order objectives and actual effects of the efforts are ultimately of greater importance and deserve increased research attention. More research needs to be done on actual impacts of industrial development on the economy and fiscal condition of the community and the health, welfare, and happiness of its citizens.

\section{FOOTNOTES}

1 For a discussion of the various federal economic development programs affecting Appalacia, see David S. Walls and John B. Stephenson (editors), Appalachia in the Sixties (Lexington: University of Kentucky Press, 1972); Frank S. Riddel (editor), Appalachia (Dubuque, Iowa: Kendall/Hunt, 1974); and Kenneth D. Rainey and Thomas A. Cotton, "Evaluation of the 1965 Economic Development Legislation," Review of Regional Studies, 1 (Winter 1970-71), pp. 73-98.

2For a discussion of state industrial development programs and activities see Benjamin Bridges, Jr., "State and Local Inducements for Industry, Part I," National Tax Journal, XVIII (March, 1965), 1-14; Linda Liston, "States Spar in Sizzling Contest for Industry," Industrial Development, 136 (November/December, 1967) 22-31; "The States-What They Give to Industry and What They Take In Return," Business Management (August, 1969), 26-31; Financing Industrial Development Through State and Local Governments, Agricultural Economic Report No. 128 (U.S. Department of Agriculture, December, 1967); and Mabel Walker, "The Role of the State in
Industrial Development," Tax Policy, XXIV (Feb.-March, 1957), 3-9.

3Local government programs are discussed in Bridges, loc. cit., Walter L. Webb; Industry and the Small City (Management Information Service, International City Management Association, November 1969, Vol. 1, No. S-11; and John E. Moes, "The Subsidization of Industry by Local Communities in the South," Southern Economic Journal, XXVIII (October, 1961), 187-193.

4This interpretation of the changing role of local government in community industrial development was suggested to the author by $\mathrm{Mr}$. Kenneth York, Industrial Commissioner of Roane County, Tennessee, (Personal interview, July, 1974).

5In Tennessee, records of the Department of Economic and Community Development for the years 1957 through 1973 indicate that in that state most industrial bond referenda passed by majorities of $90 \%$ or greater, and majorities of $95 \%$ or greater are not uncommon.

'Here, the general body of literature in industrial location is important. See, Melvin L. Greenhut, Plant Location in Theory and Prac- 
tice (Chapel Hill, N.C.: The University of North Carolina Press, 1955); David M. Smith, Industrial Location (New York: John Wiley and Sons, 1971); Edgar M. Hoover, The Location of Economic Activity (New York: McGraw-Hill, 1948).

${ }^{7}$ For general discussions of the ways in which communities may influence plant locations see L. T. Wallace and V. W. Ruttan, "The Role of Community as a Factor in Industrial Location," Papers and Proceedings of the Regional Science Association, 7 (1961); Walter L. Webb, op. cit.; Ruth L. Mace Industry and City Government (Chapel Hill, North Carolina: Institute of Government, The University of North Carolina, undated); Economic Research, U.S. Department of Agriculture. The Effects of Taxes and Public Financing Programs on Local Industrial Development (Washington, D.C.: U.S. Department of Agriculture, 1968); Mabel Walker "Local Government and Industry," Tax Policy, 25 (November, 1958), 3-8.

8Tax concessions and exemptions is a much discussed but little documented incentive for industrial location. For a survey, although somewhat dated, of the use of this inducement in Tennessee local governments, see Robert $\mathrm{R}$. Cassell, Subsidies for Industry in Tennessee, Tennessee State Planning Commission, (Nashville, Tennessee, 1947). For a more general discussion see Bridges Loc. cit. and the Advisory Commission on Intergovernmental Relations, State and Local Taxation and Industrial Location (Washington, D.C.: ACIR, 1967). There are several helpful pro and con articles with respect to the effectiveness of tax concessions. See William K. Stober, and Lawrence E. Falk. "Property Tax Exemption: An Inefficient Subsidy to Industry," National Tax Journal, XX (December, 1967); and Moes, Loc. cit.

9Robert E. Lowry, "City Subsidies to Industry Wane," National Municipal Review, XXXIV (March, 1945), pp. 112-115.

10 Bridges, op. cit., pp. 8-9.

11 Ibid., p. 8.

12Cassell, Loc. cit. A list of relevant State Supreme Court decisions are cited in this document.

13 Ibid., p. 8.

${ }^{14}$ This description is based largely on interviews with local and regional officials in the East Tennessee Development District.

15 For a discussion of the methods, advantages, and disadvantages of industrial aid bonds, see Financing Industrial Development Through State and Local Governments, (Washington, D.C.: United States Department of Agriculture, 1967); Alan B. Techner, Industrial Aid Financing, (New York: Goodbody and Company, 1965); Industrial Development Bond Financing (Washington, D.C. Advisory Commission on Intergovernmental Relations, 1963); and Arthur A. Thompson, "The Contribution of: Industrial Aid Bond Financing to Regional Economic Development," Review of Regional Studies 1 (Fall, 1970), pp. 185-210. Studies of the importance of industrial bond financing in industrial location processes is generally restricted to surveys of manufacturing execu- tives, in which bond financing is generally awarded a moderately high ranking. For a survey of the views of Tennessee manufacturers, see Ronald E. Carrier, and William R. Schriver Plant Location Analysis, (Memphis, Tennessee: Memphis State University, 1969).

$16 \mathrm{For}$ a thorough discussion of this process, see Techner, Ibid.

17Tennessee Code Annot., 6-2913 and 6-1714.

18Tennessee Code Annot., 6-1702, 6-2902, 6-2801, and 13-1301 respectively.

19Records of the Department of Economic and Community Development, State of Tennessee.

20See George W. Cox, "Planned Industrial Parks and Districts," Urban Land, 19 (JulyAugust, 1960), 3-4. Robert E. Boley, "Successful Industrial Park Development," Urban Land, 25 (June, 1967), 3-11. Kenneth Henry, "Industrial Parks: Packaged Sites for Industry," Management Review, 48 (May, 1959), 57-60. Albert E. Redman, "What is an Industrial Park?" Industrial Development 36 (May.June, 1967), 22-24.

21Tennessee Code Annot., 13-1302.

22Daniel Good, Industrial Parks in East Tennessee (Unpublished Ph.D. dissertation, The University of Tennessee, 1973).

23The EDA grant system is described in EDA Grants and Loans for Public Works and Development Facilities, U.S. Department of Commerce, Washington, D.C., 1971; and a description and partial evaluation of the Public Works and Economic Development Act of 1965 can be found in Rainey and Cotton, Loc. cit.

${ }_{24} \mathrm{EDA}$ Grants and Loans, Ibid. p. 3.

${ }^{25}$ For discussion of the structure and functions of these organizations see: Randall $\mathrm{T}$. Klemme, "Community Development as a Forerunner of Industrial Development," Appraisal Journal 28 (October, 1960), 444-448; Robert C. Norman, "Industrial Development Corporations," Georgia Business, 20 (March, 1961) 1-7; and Jacob J. Kaufman and Helmut J. Golatz, The industrial Development Corporation: Its Objectives, Functions, and Problems (University Park, Pennsylvania: The Pennsylvania University, Bureau of Business Research, 1960). For an evaluation of the effectivenes of the agencies, see Charles P. Rahe, Industrial Development Agencies and the Location of New Plants," Growth and Change, 3 (October, 1972) pp. $3-8$.

${ }_{26}$ Klemme, Ibid., p. 444.

27 Ibid.

28 Norman, op. cit., p. 1.

${ }^{29}$ Clenton J. Smith, Industrial Development of the East Tennessee Economic Development District, Background Paper No. 9 (Knoxville, Tennessee: East Tennessee Development District, 1969).

30Tennessee Code Annot., 6-2802.

31 Based on interviews with local officials in the IEast Tennessee Development District, Tennessee.

${ }^{32}$ Sie John F. Due, "Studies of State-Local Tax Influences on the Location of Industry," National Tax Journal, 14 (1961), 163-173; and 
William R. Schriver, "The Industrialization of the Southeast Since 1950," The American Journal of Economics and Sociology, 30 (January, 1971), pp. 47-70; Joe Summers Floyd, Jr., Effects of Taxation on Industrial Location, (Chapel Hill: The University of North Carolina Press, 1952); and M. L. Greenhut, Plant Location, op. cit., p. 139.

33Greenhut, Plant Location, op. cit., p. 139; Carrier and Schriver, op. cit., p. 70; and Floyd, Ibid., pp. 3-26.

${ }^{34}$ Greenhut, op. cit., p. 103; Due, op. cit., p. 23.

35See Zenon S. Malinowski and William N. Kinnard Jr., in Personal Factors Influencing Small Manufacturing Plant Locations (Storrs, Conn.: University of Conn., 1961), pp. 1-5. James H. Thompson, Methods of Plant Site Selection Available to Small Manufacturing Firms, (Morgantown, West Virginia: West Virginia University, 1961); pp. 27-56; and Robert D. Dean, "Plant Location Decision Process," Review of Regional Studies 8 (Fall 1972-73) pp. 1-13.

36For example, see Greenhut, Plant Location, p. 103, and Benjamin Bridges Jr., "State and Local Inducements for Industry, Part II," National Tax Journal 18 (June, 1965), pp. 175189.

37The Directory of Tennessee Industries, 1960, 1963, 1966, 1969, and 1973 editions, the
Tennessee Staff Division for Industrial Development (Nashville, Tennessee).

38These data have been compiled and published by Charles R. Meyers, Osbin L. Ervin, Donald L. Wilson, and Peter A. Leslie, Spatial Distributions and Employment Trends in East Tennessee (1943-1973), ORNL - NSF - EP - 38 (Oak Ridge, Tennessee: Oak Ridge National Laboratory, 1974).

${ }^{39}$ All statistical analyses were performed using Norma H. Nie, Dale H. Bent, Jean G. Jenkins, Karin Steinbrenner, and Aadlai C. Hull, Statistical Package for the Social Sciences, second edition (New York: McGrawHill Book Company, 1975).

${ }_{40}$ No useful purpose would be served by identifying the municipalities of the ETDD. Therefore, all the names used are pseudonyms.

${ }^{41}$ The only major intercorrelation among these four variables is a .6032 between the dollar volume of industrial aid bonds and the industrial park index. This is not unexpected. As was noted earlier, industrial aid bonds are used in the development of industrial parks.

42 For a more thorough discussion of the relationship between regional science and the needs of local and regional decision-makers, see Robert T. Miki, "Regional Science and Public Policy," Review of Regional Studies 7 (Spring, 1972), pp. 5-11. 